LRH: Adame et al.

RRH: Mangrove Litterfall in the Yucatan Peninsula

\title{
Drivers of Mangrove Litterfall within a Karstic Region Affected by Frequent Hurricanes.
}

Ma. Fernanda Adame ${ }^{1 *}$, Arturo Zaldívar-Jimenez ${ }^{1}$, Claudia Teutli ${ }^{1}$, Juan Pablo Caamal ${ }^{1}$, María Teresa Andueza ${ }^{1}$, Haydée López-Adame ${ }^{2}$, Romel Cano ${ }^{3}$, Héctor A. Hernández-Arana ${ }^{2}$, Ricardo Torres-Lara $^{3}$, Jorge A. Herrera-Silveira ${ }^{1}$

${ }^{1}$ CINVESTAV-IPN, Unidad Mérida. Antigua Carretera a Progreso km.6, Mérida Yucatán, México, C.P. 97310.

${ }^{2}$ ECOSUR, Unidad Chetumal, Av. del Centenario Km. 5.5 Chetumal, Quintana Roo, México. C.P. 77900

${ }^{3}$ Universidad de Quintana Roo, Mexico. Boulevard Bahía s/n esq. Ignacio Comonfort, Col. del Bosque Chetumal, Quintana Roo, México C.P. 77019

*Corresponding author

mfadame@mda.cinvestav.mx

Received ; revision accepted 


\section{ABSTRACT}

Tropical storms can shape the structure and productivity of mangrove forests. In this study, we compared current litterfall with historical tropical storm disturbance in the karstic Yucatan Peninsula (YP). We also explored the relationship between litterfall and the fresh/seawater mixture of floodwater. Our hypotheses were that litterfall peaks at moderate perturbations and in sites where seawater dominates the floodwater mixture, and thus, where soil total phosphorus (TP) is relatively high. Litterfall was sampled for two years, from eight mangrove forests around the YP. At each site, forest structure, interstitial salinity, TP, nitrogen, carbon, $\mathrm{pH}$, and bulk density were measured. Our results show that mangrove forest from northeast YP are historically impacted by stronger and more frequent tropical storms compared to those in northwest and southeast YP, where tropical storm intensity is moderate and mild, respectively. Litterfall was higher in northwest YP ( $\geq 3 \mathrm{~g} / \mathrm{m}^{2} \mathrm{~d}$ ) compared to northeast and southeast ( $\left.\leq 2 \mathrm{~g} / \mathrm{m}^{2} \mathrm{~d}\right)$, mimicking a subsidy-stress gradient where highest productivity is reached at moderate perturbations. Neither salinity nor forest structure alone satisfactorily explained litterfall variability. Soil TP followed a similar geographical pattern as the disturbance gradient, with the highest concentrations in the northwest YP ( $\geq 0.05 \%)$ and lowest in the northeast and southeast $(\leq 0.03 \%)$. Thus it is likely that $\mathrm{TP}$, and not tropical storm disturbance, is the main driver of litterfall in mangrove forests of the YP. Alterations in TP availability (e.g. sea level rise and aquifer contamination) have the potential to modify mangrove productivity in the region. 
Keywords: groundwater; nutrients; phosphorus; perturbation; tropical storms; wetlands; Yucatan Peninsula 


\section{RESUMEN}

Las tormentas tropicales afectan la estructura y productividad de los bosques de manglar. En este estudio, se comparó la producción de hojarasca con la perturbación histórica de tormentas tropicales en la Península de Yucatán (PY). También se investigó la relación entre la producción de hojarasca y la mezcla de agua fresca/marina que inunda a los bosques. Las hipótesis fueron que la producción de hojarasca es mayor en bosques sujetos a perturbaciones moderadas y en bosques inundados por agua predominantemente marina, y por tanto, donde el fósforo total (FT) es relativamente alto. Se recolectó hojarasca durante dos años en ocho bosques de manglar. En cada bosque se midió la estructura, salinidad intersticial, FT, nitrógeno, carbono, pH, y densidad del suelo. Los resultados muestran que los bosques de manglar del noreste de la PY son afectados con mayor frecuencia e intensidad por tormentas tropicales en comparación con los bosques del noroeste y sureste, dónde el impacto es moderado y bajo, respectivamente. La producción de hojarasca fue mayor en el noroeste $\left(\geq 3 \mathrm{~g} / \mathrm{m}^{2} \mathrm{~d}\right)$ comparada con el noreste y sureste ( $\left.\leq 2 \mathrm{~g} / \mathrm{m}^{2} \mathrm{~d}\right)$, semejando un gradiente estrés-subsidio donde la mayor producción se encuentra a perturbaciones moderadas. La estructura del bosque y salinidad no explicaron la variabilidad de la producción de hojarasca. Sin embargo, la concentración de FT en el suelo varió de la misma forma que el gradiente de perturbación: mayores concentraciones en el noroeste ( $\geq 0.05 \%$ ) comparadas con el noreste y sureste de la PY ( $\leq$ 0.03 \%). Es probable que la variabilidad de la producción de hojarasca de la PY sea causada más que por la intensidad de las tormentas tropicales, por variaciones en FT. Modificaciones en la disponibilidad de FT (e.g. aumento en el nivel del mar, 
contaminación del acuífero) podrían alterar la producción de los manglares de esta región. 
MANGROVE FORESTS DOMINATE THE COAST OF TROPICAL AND SUBTROPICAL REGIONS.

They provide a range of environmental services, which has resulted in their high

ecological and economic value (Costanza et al. 1997). Mangroves stabilize and protect shorelines (Barbier 2006), provide habitat for many economically important species (Mumby 2006), and improve the water quality of creeks and rivers adjacent to them (Adame et al. 2010). Mangroves are productive ecosystems with high carbon sequestration potential (Twilley et al. 1992). The high productivity of mangroves is likely to subsidize coastal production as mangroves export particulate carbon and litter to coastal shores (Adame \& Lovelock 2011).

Litter is a component of aboveground mangrove production accounting for approximately 32 percent of total production (Bouillon et al. 2008). Litterfall is variable among sites and has been correlated with latitude and tree height, with highest litterfall measured at tropical latitudes, where forests can reach their highest structural forms (Saenger \& Snedaker 1993). Litterfall is also a function of forest type (Lugo et al. 1988), precipitation, temperature, and salinity (Day et al. 1996). High litterfall rates occur in conditions of high temperature, high rainfall, and low salinity (Day et al. 1996), or when strong winds cause wood breakage and temporal defoliation (Doyle et al. 1995).

Strong winds in the Caribbean are associated with tropical storms and hurricanes that can strongly modify mangrove forest structure and productivity. Over a short time scale, hurricanes can cause a rapid defoliation of up to 60 percent of mangrove trees resulting in an immediate but temporary increase in litterfall (Doyle et al. 1995), followed by a period of low litterfall until the forest recovers from the damage. Hurricanes can also result in blow downs of up to 100 percent of the mangrove trees 
(Doyle et al. 1995). Over a longer time scale, frequent hurricanes shape the mangrove ecosystem to a poor developed forest with low structural complexity (Roth 1992). Frequent hurricanes can decrease the potential productivity by decreasing the relative height and structure of the forest (Doyle et al. 1995). Alternatively, hurricanes can increase production by alleviating nutrient limitation (Lovelock et al. 2011). Hurricanes can also increase habitat availability by delivering sediment inputs (Conner et al. 1989). Finally, hurricanes modify species composition of mangrove forests; different species have different capacities to withstand wind forces, long periods of flooding, and to recolonize areas after hurricanes (Baldwin et al. 2001). The immediate effects of hurricanes on mangroves have been widely recognized, however long-term effects of hurricanes in mangrove productivity are poorly understood.

The Caribbean region has been historically affected by hurricanes; 620 tropical storms have been recorded in this basin since 1850 (NOAA, 2011). From June to November, the Atlantic Ocean warms up and low-pressure systems form and travel west or northwest of the Caribbean Ocean where they reach the Yucatan Peninsula (YP), Mexico. Mangroves in the YP are frequently impacted by tropical storms and hurricanes, and it is likely that these climatic events have historically shaped the structure and productivity of these forests.

Mangroves of the YP are characterized by frequent hurricane disturbance, but they are also characterized by a karst system composed of a carbonate substrate, which is highly permeable (Steinich \& Marín 1996). The permeable substrate results in a lack of surface rivers and a complex underground water system (Schmitter-Soto et al. 2002), where fresh groundwater travels towards the coast and mixes with seawater before 
discharging into the ocean (Beddows et al. 2007, Bauer-Gottwein et al. 2011). As a result, coastal wetlands in the YP are flooded by a mixture of fresh and seawater; the former characterized by relatively low salinity, low phosphorus $\left(<1 \mu \mathrm{mol} \mathrm{L}{ }^{-1}\right)$ and high nitrate concentrations ( $>50 \mu \mathrm{mol} \mathrm{L}{ }^{-1}$ ) and the later characterized by relatively high salinity, high phosphorus, and low nitrate concentrations (Aranda-Cicerol et al. 2006, Hernández-Terrones et al. 2011). Variations in the mixture of fresh and seawater flooding mangrove forests of the YP can influence interstitial salinity and nutrient availability, which are likely to affect primary production.

In this study, we aim to compare current litterfall of mangrove forests of the YP to (1) historical storm and hurricane frequency and to (2) soil nutrient concentrations and interstitial salinity, which reflect the proportion of fresh/seawater mixture of the floodwater. Our first hypothesis is based on the Perturbation Theory by Odum et al. (1979), which suggests a subsidy-stress gradient from which can be predicted highest ecosystem performance at moderate perturbations. We hypothesize that highest litterfall is found at sites with historical moderate storm and hurricane disturbance. For our second hypothesis, we predict a litterfall gradient following soil phosphorous concentrations and interstitial salinity: mangrove forests where floodwater has a proportionately large contribution of fresh groundwater will have relatively low soil phosphorus and low litterfall. In order to test our hypotheses, we obtained litterfall rates from two years (2009-2010), forest structure, and soil characteristics of eight mangrove forests distributed within the YP coast. This study comprises the first quantitative study on the effects of historical hurricane disturbance on mangrove litterfall in a karstic region and the most comprehensive litterfall dataset for the Wider Caribbean. 


\section{METHODS}

STUDY SITES-The YP is situated in Southeast Mexico and comprises the states of Campeche, Yucatan, and Quintana Roo. It is surrounded by the Caribbean Sea on the east side and the Gulf of Mexico in the north and west side (Fig.1). Tides are predominantly semidiurnal in the east coast (amplitude $<25 \mathrm{~cm}$ ) and diurnal in the west coast (amplitude $<15$ cm) (Centro de Investigación Científica y Educación Superior de Ensenada, 2011). Mangroves surround the coasts of the YP with a total area of 423,751 ha (National Commission on Biodiversity; CONABIO 2009). The mangrove forests in YP are primarily composed of Rhizophora mangle, with lower abundance of Laguncularia racemosa, Avicennia germinans and Conocarpus erectus. In areas with large freshwater inputs (e.g. Chetumal), mangrove forests can be associated with terrestrial plants such as Pachira sp.

The climate in the YP is tropical, warm semi-dry in the west coast, warm dry in the north and warm sub humid in the east coast (García \& Mosiño 1992). Hurricanes and tropical storms are common from August until November (Servicio Meteorológico Nacional-Comisión Nacional del Agua; SMN-CNA). Mean temperature is $26^{\circ} \mathrm{C}$ with a mean annual minimum of $15^{\circ} \mathrm{C}(1970-2010)$ and mean annual maximum of $31^{\circ} \mathrm{C}(1951-$ 2008), annual rainfall ranges from 750 to 1000 mm (1941-2005) (SMN-CNA). During 2009, the mean annual rainfall in the northwest of the YP was $736 \mathrm{~mm}$ and in the east was $1261 \mathrm{~mm}$. During 2010, rainfall increased to $1072 \mathrm{~mm}$ in the northwest and to 1504 $\mathrm{mm}$ in the east. 
EXPERIMENTAL DESIGN- Eight mangrove forests distributed around the YP coast were chosen as our sampling sites (Fig. 1). Fringe mangroves forests were chosen because most of tropical storm or hurricane effects by winds is restricted to $200-300 \mathrm{~m}$ from the seaward edge (Ross et al. 2006). The exception was Puerto Morelos, which is a basin forest and has no direct connection to the sea; in this location, our sampling site was as close as possible to the sea edge ( $<80 \mathrm{~m}$ of forest edge and $<200 \mathrm{~m}$ from the sea). All sites have low to medium nearby urban, agricultural and livestock development, which could result in anthropogenic nutrient inputs. From our study sites, Chelem, Yucalpeten, Rio Lagartos and Puerto Morelos are the most likely to be affected (Aranda-Cicerol et al. 2006, Hernández-Terrones et al. 2011).

Each of the sampling sites has historically been impacted by tropical storms and hurricanes at various frequencies and intensities (Table 1), but not during the years litterfall was sampled (2009-2010). However, one of the sites -Chetumal- was affect by storm like-winds ( $\sim 5 \mathrm{~km} / \mathrm{h}$ ) resulting from Hurricane Alex which stroke Belize in June 2010 and by tropical storm Karl in September of the same year.

To obtain a numerical value of the intensity and frequency of storm activity in each location, we calculated a Tropical Storm Index (TSI). First, we counted the number of storms and hurricanes that crossed over a $40-\mathrm{km}$ radius of the sampling sites from 1857 to 2009 using the hurricane track dataset from NOAA (2011). We chose the radius length based on Doyle et al. (1995) who calculated that the effects of a category fivehurricane reaches $40 \mathrm{~km}$ from the hurricane’s eye. The physical effect towards mangroves caused by hurricanes is critical when wind speeds exceed $144 \mathrm{~km} / \mathrm{h}$, i.e., a 
strong category one hurricane (Doyle et al. 1995). However, tropical storms and milder category one hurricanes may also alter mangrove forests by delivering additional freshwater and nutrients (Lovelock et al. 2011), and were included in the TSI analysis. To simplify, herein we will refer to both storms and hurricanes as "tropical storms". Each climatic event was given a value of strength by multiplying it by its mean wind velocity as reported by NOAA (2011). Based on the Saffir-Simpson hurricane classification, mean wind velocities were considered to be $90 \mathrm{~km} / \mathrm{h}$ for storms and 135, 165, 194, 230 and 290 $\mathrm{km} / \mathrm{h}$ for hurricane categories one to five. The sum of all the events for each site was numerically transformed to obtain the TSI (Equation 1). The TSI was used to correlate the effect of historical tropical storm disturbance with current mean mangrove litterfall. The TSI of each site is shown in Table 1. Equation 1.

$\mathrm{TSI}=\sum\left(N_{x}{ }^{*} \mathrm{v}_{x}\right) / 1000$

Where:

$$
\begin{aligned}
\text { TSI } & =\text { hurricane index } \\
N & =\text { number of events } \\
\mathrm{v} & =\text { mean wind velocity }(\mathrm{km} / \mathrm{h})
\end{aligned}
$$

FIELD SAMPLING- Two permanent $100 \mathrm{~m}^{2}$ plots were established at each site, except in Puerto Morelos, where three plots were set ( $N=17$ plots). Within each plot, interstitial salinity, soil pH, bulk density, soil nutrients (nitrogen, $\mathrm{N}$ and total phosphorus, $\mathrm{TP}$ ), soil carbon (C), forest structure, and litterfall were measured. 
INTERSTITIAL SALINITY- During each sampling campaign, soil interstitial water was extracted from the ground at $30 \mathrm{~cm}$ depth using a syringe and an acrylic tube. The syringe was rinsed twice before obtaining a clear water sample from which salinity was measured using an YSI-30 multiprobe sensor (YSI, Xylem Inc. Ohio, U.S.A.).

SolL- pH was measured at each plot using a pH-meter (Digi-Sense, Cole Parmer Instrumentation Co. Illinois, USA). At each plot, $6.5 \mathrm{~cm}$ diameter cores were taken, from which four samples were collected from the upper $10 \mathrm{~cm}$ surface layer; one core per plot was sampled from Rio Lagartos and Chetumal and two cores per plot at Yucalpeten, Chelem, Celestun, Dzilam, Puerto Morelos and Xcalak, $(N=30$ cores, $N=120$ sediment samples). Samples were taken to the laboratory where they were oven-dried at $60^{\circ} \mathrm{C}$ and weighted. Bulk density was calculated as the dry weight of the sample divided by its volume. Soil TP was measured as orthophosphates using the methodology described by Aspila et al. (1976) and Parsons et al. (1984). For N and C, soil samples were analyzed in an Elemental Analyzer (FlashEA 1112, Thermo Quest, Milan, Italy).

FOREST STRUCTURE -. Within each plot, all the trees were counted and identified. The diameter at breast height (DBH) was measured for each tree of L. racemosa and A. germinans whose diameter was larger than $2.5 \mathrm{~cm}$. For trees of $R$. mangle, the diameter above the highest prop root was measured following guidelines by Dahdouh-Guebas and Koedam (2006). The height of each tree was measured using a LaserAce ${ }^{\circledR}$ rangefinder (MDL, Laser Systems, UK). Mean tree height, tree density, basal area (BA) and species composition of each plot were calculated following methodology by Cintrón and 
Shaeffer-Novelli (1984). A complexity index (CI) was calculated for each site following guidelines by Holdrige et al. (1971).

LITTERFALL - At each plot, five litter catchers were attached to trees at a height of $1.3 \mathrm{~m}$ $(N=85)$. The litter catchers had an area of $0.25 \mathrm{~m}^{2}$ and were made of fine mesh $(1 \mathrm{~mm})$. The locations of the litter catchers within each $100 \mathrm{~m}^{2}$-plot were randomly selected and were separated from each other by at least three meters. In one of our sites (Chetumal), the forest is composed of mangrove trees associated with patches of terrestrial vegetation that grow on elevated areas. In this location, we deliberately avoided areas composed of only terrestrial plants and set the litter catches in areas dominated by mangrove trees. Litter within the nets was collected monthly (Celestun, Yucalpeten, Chelem, Dzilam, and Chetumal) or bimonthly (Rio Lagartos, Puerto Morelos, and Xcalak) throughout 2009 and 2010. The collected litter was transported to the laboratory and oven dried at $60^{\circ} \mathrm{C}$. Litter was separated by species and by components (leaves, fruits and flowers, twigs and miscellaneous, i.e., non recognizable components) and weighted. Litterfall is shown as grams of dry weight per square meter per day.

STATISTICAL ANALYSES- Differences among sites for interstitial salinity, soil characteristics (bulk density, $\mathrm{pH}$, soil C, N, P, and N:P), forest structure (tree density, tree height, BA, and CI) and litterfall were tested using One way Analysis of Variance (ANOVA), where "plot" (nested in "site") was the random factor and site was the fixed factor of the model. Scheffé and Fisher’s Least Significance Difference (LSD) post-hoc tests were calculated. The difference in litterfall between years was tested using a 
Repeated Measurements ANOVA, where year was the repeated measurement and plot was nested within each site. Nutrients, forest structure, and litterfall were transformed (square root or log) in order to comply with normality and homogeneity of variances. In order to facilitate the visualization of the data (i.e. eliminate negative numbers), log TP was transformed (+2). Sites were grouped according to their soil characteristics and forest structure using a Principal Component Analysis (PCA). The soil characteristics for each site were calculated as the mean of the plots, which were calculated as the mean of the cores within each plot. Correlation between TSI and litterfall was assessed using nonlinear (quadratic) relations. Two Step-wise Multiple Regressions were conducted, the first to assess the effect of abiotic characteristics on litterfall, and the second to assess the effect of forest structure. To assess multicolinearity among variables, we calculated a variance inflation factor (VIF) for each parameter. Models with low VIF $(<4$; O’Brien 2007) were selected. All analyses were performed using Data Desk (version 6.2, OSX, Ithaca, NY, U.S.A.). Throughout the results, all values are presented as mean \pm standard error.

\section{RESULTS}

TROPICAL StORM INDEX- Rio Lagartos and Puerto Morelos have historically (1857-2009) the greatest influence of tropical storms, both in terms of frequency and intensity (TSI of 3.2 and 3.7, respectively) and Xcalak and Chetumal the lowest (TSI of 1.9 and 1.7, respectively) (Table 1). As a general trend, highest TSI values are found in northeast YP, moderate in the northwest and low in the southeast (Fig. 1). 
INTERSTITIAL SALINITY- Salinity was significantly different among sites $\left(F_{7,16}=53.26, P\right.$ $\leq 0.0001)$ and had a wide range, from a site mean of $3.1 \pm 2.4$ measured at Chetumal (mean minimum and mean maximum of $0-7$ ) to a site mean of $61.0 \pm 13.9$ measured at Yucalpeten (27-74) (Table 2). Salinity also varied within sites throughout the year, with lowest values measured at the end of the wet season $\left(F_{2,20}=8.39, p=0.005\right)$.

SoIL- Bulk density was significantly higher in Yucalpeten $\left(0.81 \pm 0.19 \mathrm{~g} / \mathrm{cm}^{3}\right)$ and Xcalak $\left(0.90 \pm 0.01 \mathrm{~g} / \mathrm{cm}^{3}\right)$ compared to the rest of the sites $\left(F_{7,15}=10.46, P=0.003\right)$ (Table 2). Soil pH, C and N were similar among sites, but soil TP was lowest in eastern YP (Rio Lagartos, Puerto Morelos, Xcalak and Chetumal), intermediate at Yucalpeten and Dzilam and highest at Celestun and Chelem $\left(F_{7,16}=30.97, P \leq 0.0001\right)$. Lowest N:P were measured at Chelem, and Dzilam and highest at Rio Lagartos and Chetumal $\left(F_{7,16}=\right.$ 17.55, $P=0.003$ ) (Table 2).

According to their physicochemical characteristics, the sites were grouped: (1) northwest YP with high soil TP and high salinity (upper right of the graph), (2) northeast YP with low TP, and high N and C (left of the graph), and (3) southeast YP with low TP and low C (below, right of the graph) (Fig. 2A). From all the variables considered, soil TP was the most important factor that explained inter-site variability, followed by N, C, salinity, bulk density, and $\mathrm{pH}$. The grouping of the study sites based on the PCA reflects their geographical location (Fig. 1), which suggests large-scale patterns of variability among mangrove forests of the YP. 
FOREST STRUCTURE- The density of the forest had a mean of $3660 \pm 662$ trees/ha and was significant different among sites $(F 7,16=5.57, P=0.014)$. Mean height was $4.2 \pm 0.4 \mathrm{~m}$, with highest trees found at Chetumal and shortest at Yucalpeten $\left(F_{7,16}=41.70, P \leq\right.$ 0.0001). Mean BA of all the sampled sites was $16.6 \pm 4.0 \mathrm{~m}^{2} / \mathrm{ha}$ with Celestun, Chelem, Puerto Morelos, Xcalak and Chetumal ( $\left.15-32 \mathrm{~m}^{2} / \mathrm{ha}\right)$ having the highest values and Rio Lagartos the lowest $\left(2.1 \mathrm{~m}^{2} / \mathrm{ha}\right)\left(F_{7,16}=15.8, P \leq 0.0001\right)$. Finally, the CI mean was $6.2 \pm$ 2.1, with highest CI at Puerto Morelos (17.6 \pm 9.3) and lowest at Yucalpeten y Rio Lagartos $(\sim 1)\left(F_{7,16}=8.86, P=0.003\right)($ Table 3$)$.

The sites were grouped according to their structure in roughly four groups (Fig. 2B): (1) Celestun, Chelem, and Chetumal (right of graph) with high trees of large BA; (2) Puerto Morelos and Xcalak with high density of medium height trees of medium BA (below); (3) Rio Lagartos and Dzilam with trees of medium height and low BA (upper left); and (4) Yucalpeten, which stands alone as a site with low trees of low BA (left).

LitTERfALL- Mean litterfall was significantly lower at Rio Lagartos, Puerto Morelos, Chetumal, and Xcalak compared to Celestun, Yucalpeten, Chelem, and Dzilam $\left(F_{7,165}=6.91, P<0.0001\right)$. Litterfall was higher in 2010 compared to 2009, with significant inter annual differences for Rio Lagartos $\left(F_{7,165}=10.49, P=0.001\right)$ (Table 4). Most litter was composed of leaves (70.3\%), followed by fruits and flowers (12.2\%), twigs (8.9\%) and miscellaneous components (8.6\%) (Fig. 3).

None of the sampled sites were affected by tropical storms during the sampling period except Chetumal, which was impacted by storm like-winds ( $55 \mathrm{~km} / \mathrm{h})$ during June 2010 and by a tropical storm during September of the same year. After the former, 
litterfall temporary increased by 56 percent $\left(4.16 \mathrm{~g} / \mathrm{m}^{2} \mathrm{~d}\right.$ compared to the mean seasonal rate of $2.70 \mathrm{~g} / \mathrm{m}^{2} \mathrm{~d}$ ) and then decreased by $12.1 \%$ in the following month. The latter did not result in a considerable increase or decrease in litterfall $(<7 \%$ of difference compared to the mean seasonal rate).

HISTORICAL TROPICAL STORM ACTIVITY AND LITTERFALL- The TSI was significantly correlated with litterfall in a nonlinear way and was represented by a quadratic curve ( $\mathrm{y}=$ $\left.-1.46 \mathrm{x}^{2}+7.60 \mathrm{x}-6.83 ; R^{2}=0.79, F_{2,5}=9.15, P=0.009\right)$. Sites at the lowest and highest spectrum of the TSI (i.e. very low and very high frequency and intensity of hurricanes), which corresponded to sites in the southeast and northeast of the YP, had lower litterfall compared to sites in the middle range of the TSI, which corresponded to sites in the northwest (Fig. 4). Production of reproductive component of litter (fruits and flowers) followed a similar trend, however the correlation with the TSI was not significant. TSI was not significantly correlated with any other parameter included in this study.

MULTIVARIATE ANALYSIS- First, we tested the effect of abiotic characteristics on litterfall. The model that best explained litterfall within our study sites and had the lowest colinearity $\left(\mathrm{VIF}=1.5 ; R^{2}=0.86, \mathrm{~F}_{2,5}=15.4,\right)$ included $\mathrm{N}(P=0.032)$ and $\mathrm{TP}(P=$ 0.050), such that sites with relatively high soil TP and low $\mathrm{N}$ had the highest litterfall. Thus, litterfall was correlated with soil TP $\left(R^{2}=0.62, F_{1,6}=9.72, P=0.021\right)$ (Fig. 5) and inversely correlated with $\mathrm{N}: \mathrm{P}\left(R^{2}=0.60, F_{1,6}=8.86, P=0.025\right)$. The reproductive components of litter were not significantly correlated with soil characteristics. Secondly, we compared forest structure (tree density, height, and BA) with litterfall. The results 
from the regression showed that none of the structural variables were significantly correlated, neither with the production of total litterfall, nor with the production of litter from reproductive components.

\section{DISCUSSION}

Litterfall is variable along the YP coast; higher litterfall rates were measured in the northwest compared to the northeast and southeast of the Peninsula. The geographical distribution of our sites mimicked a perturbation gradient with strong and frequent tropical storms ( $>1$ tropical storm per decade) for sites in the northeast; moderate intense and frequent storms ( 1 tropical storm per decade) in the northwest; and mild and infrequent ( $<1$ tropical storm per decade) storms in the southeast. Our initial hypothesis was based on the Perturbation Theory by Odum et al. (1979), which suggests a subsidystress gradient from which can be predicted highest ecosystem performance at moderate perturbations. We predicted that frequent and strong tropical storms result in higher physical disturbance and higher soil nutrients, and that infrequent tropical storms result in lower physical disturbance and lower soil nutrients. Our results do not support this idea; soil $\mathrm{N}$ was similar among sites and soil TP peaked at sites with intermediate tropical storm disturbance. Thus, storm disturbance was not correlated with the long-term accumulation of nutrients in mangrove forest soils of the YP. On the other hand, TP concentrations were higher in the northwest compared to the northeast and southeast of the YP, and litterfall was significantly correlated with soil TP. Thus, it is more likely that the differences in litterfall in the YP are due to differences in soil TP than to historical intensity of tropical storms. 
In our second hypothesis we predicted that low litterfall was associated with low soil TP and low interstitial salinity, reflecting floodwater with high fresh groundwater contributions. In our data set we observed important differences in salinity among sites, but mean annual salinity was not correlated with litterfall, probably because it is soil TP, not salinity, the most important influence in plant production in the YP and other karstic regions (Feller 1995; Rejmankova 2001). However, in forests where mean minimum salinity was relatively low ( $\leq 20$, Xcalak, Chetumal and Puerto Morelos) soil TP was also low ( $\leq 0.03 \%)$; comparatively, forests where mean minimum salinity was high, soil TP was also high ( $\geq 20$; $\mathrm{TP} \geq 0.03 \%)$. In the karstic YP, phosphorus in groundwater is largely unavailable due to its precipitation to insoluble forms in the presence of calcium carbonate. It is likely that the proportion of fresh groundwater to the floodwater mixture contributes to some extent to soil TP concentrations. However, the contribution could vary throughout the year due to temporal variations in groundwater discharge (Gondwe et al. 2010).

Fresh groundwater contribution to floodwater is likely to be higher in mangrove forest from eastern YP, where rainfall -and probably groundwater discharge- is typically $\sim 30 \%$ higher than in the northwest coast (SMN-CAN), which could account for higher TP in the west compared to the east YP. Furthermore, mangrove forest from the northwest coast are flooded by water from the Gulf of Mexico, which is typically higher in phosphorus (soluble reactive phosphorus, mean SRP $=0.41 \mu \mathrm{mol} \mathrm{L}-1$; $0.03-1.7 \mu \mathrm{mol}$ $\mathrm{L}^{-1}$, Aranda-Cicerol et al. 2006) compared to the Caribbean Sea (SRP $=0.08 \pm 0.0 \mu \mathrm{mol}$ L ${ }^{-1}$; Hernández-Terrones et al. 2011), which floods mangrove forests from the eastern coast. In the northeast of the YP, during the offset of the Cabo Catoche upwelling, there 
is an important increase in nutrients, which are transported west (Enriquez et al. 2010), adding up to the nutrient availability of mangrove forests in northwest YP. Finally, rainfall might also be important in determining soil TP. From 2009-2010, rainfall increased by 16-42 percent in the YP. Similarly, mean litterfall significantly increased by 10 percent (1-28\%), suggesting that besides freshwater inputs, episodic rainfall might mobilize terrestrial TP and other nutrients to mangrove forests.

Mangrove productivity is affected by soil nutrients (Feller 1995), but a review by Saenger \& Snedaker (1993) (using a data set of trees ranging from 2 to $30 \mathrm{~m}$ ), demonstrated that tree height and latitude were the most important factors that explained pantropical litterfall. This is not the case for fringe forests of the YP. For example, some of the tallest trees are found at Celestun and Chetumal (mean of 5.3 and $5.7 \mathrm{~m}$, respectively), but litterfall is significantly higher in Celestun $\left(2.90 \pm 0.34 \mathrm{~g} / \mathrm{m}^{2} \mathrm{~d}\right)$ compared to Chetumal $\left(1.96 \pm 0.23 \mathrm{~g} / \mathrm{m}^{2} \mathrm{~d}\right)$. Likewise, Yucalpeten has the shortest trees from all the sampled sites (mean of $2.0 \mathrm{~m}$ ), however litterfall in this site $(2.94 \pm 0.25$ $\left.\mathrm{g} / \mathrm{m}^{2} \mathrm{~d}\right)$ is significantly higher than in Puerto Morelos $\left(1.69 \pm 0.15 \mathrm{~g} / \mathrm{m}^{2} \mathrm{~d}\right)$, site with a mean tree height of $4.3 \mathrm{~m}$. Species composition did not explain litterfall either. For example Rhizophora mangle has higher litterfall compared to other species such as Avicennia marina and Conocarpus tagal (Bunt 1995). However, litterfall in sites dominated by Avicennia (Celestun and Yucalpeten) was 35 percent higher $\left(\sim 3 \mathrm{~g} / \mathrm{m}^{2} \mathrm{~d}\right)$ compared to sites dominated by Rhizophora mangle (Xcalak, $\sim 2 \mathrm{~g} / \mathrm{m}^{2} \mathrm{~d}$ ). Across the structural variability sampled within our sites (i.e. fringe forests of $\sim 2-5 \mathrm{~m}$ in height), characteristics of the forest alone (height, BA, density, CI, species composition) could not explain litterfall. Frequent tropical storm disturbance in the YP could result in a highly 
dynamic system that is constantly renovating (cycles $<25$ yr; Lugo \& Snedaker 1974). By sampling mangrove forests for two years, we can only get a snapshot of the potential production and structure of the forest, which is constantly changing. The data from this study suggests that the production potential, and maybe, the recovery capacity of mangroves in the YP is mostly driven by TP.

The mean litterfall of the mangroves of the YP is $2.41 \pm 0.26 \mathrm{~g} / \mathrm{m}^{2} \mathrm{~d}(1.69-3.48$ $\mathrm{g} / \mathrm{m}^{2} \mathrm{~d}$ ), which is equivalent to $8.8 \mathrm{ton} / \mathrm{ha} \mathrm{yr}$, is within the mid range compared with global litterfall (1.3-18.7 ton/ha yr; Saenger \& Snedaker 1993). Litterfall in the YP is similar to that of other Caribbean regions affected by frequent tropical storms such as Puerto Rico (9.7 ton/ha yr; Pool \& Snedaker 1975) and higher than those in Florida (5.5 ton/ha yr; Lugo \& Snedaker 1974). Comparing litterfall in the YP with sites in the Southern Hemisphere affecter by similar climatic events, rates from the YP are within those measured in northern Australia (2.3-10.5 ton/ha yr; Bunt 1995), but lower than those for Papua New Guinea (14.3 ton/ha yr; Leach \& Burgin 1985). The mean TP concentration from our sites were variable $(<0.02-0.10 \%)$, with values within ranges measured in other mangrove forests (Australia and Sierra Leone, 0.01-0.13\%, Alongi et al. 1992, and references therein), mangroves in Gazi Kenya $(<0.01-0.07)$ (Middelburg et al. 1996) and lower than those of an arid mangrove forest (Gulf of Baja California, 0.14\%; Vazquez et al. 2000). Salinity values in some of our study sites were lower than those measured in riverine mangrove forests (annual mean of 6 in Chetumal, compared to 15-18; Guayas River, Ecuador, Twilley et al. 1997) and as high as in hypersaline scrub forests (62 in Yucalpeten compared to 32-55 in Florida; Lovelock \& Feller 2003). 
In this study, we propose that mangrove forests in the YP can be divided into three regions according to productivity, soil characteristics and tropical storm perturbation. The 1) northwest coast, characterized by high litterfall, high soil TP and moderate storm perturbation, 2) northeast coast, with low litterfall, low soil TP and high tropical storm perturbation, and 3) southeast coast, with low litterfall, low soil TP and low tropical storm perturbation. Litterfall in the YP seems to be mainly driven by soil TP, whose variability could be explained as a result of the proportion of fresh groundwater to the floodwater mixture, and phosphorus concentrations of marine floodwater. Sea level rise, groundwater pollution and overexploitation of the aquifer are likely to increase saltwater intrusions (Bauer-Gottwein et al. 2011) and TP availability (HernándezTerrones et al. 2011), thus potentially altering the production of mangrove forests in the region.

\section{ACKNOWLEDGMENTS}

We would like to thank CINVESTAV-IPN (Research Centre and Posgraduate Studies of the National Polytechnic Institute), Mérida and CONACyT (Mexican Council of Science and Technology) for financial and logistical support. This research was supported by the CONACYT-FOMIX, YUCATAN (YUC-2006-C05-66223) and CONABIO (FN009) grants. We would like to thank for field and laboratory assistance Javier Ramirez, Ileana Osorio and Elsy Alvarado who are part of Primary Production Lab at CINVESTAV-IPN. Special thanks to Dr. Victor Rivera Monroy for stimulating discussions on structure and function of mangrove ecosystems in karstic settings. 


\section{LITERATURE CITED}

ADAME, M. F., D. VIRIDS AND C. E. LOVELOCK. 2010. Effect of geomorphological setting and rainfall on nutrient exchange in mangroves during tidal inundation. Mar. Fresh. Res. 61:1197-1206

AdAme, M. F. AND C. E. LOVELOCK. 2011. Carbon and nutrient exchange of mangrove forests with the coastal ocean. Hydrobiol. 663: 23-50.

Alongi, D.M., K.G. Boto AND A. I. RoBerTson. 1992. Nitrogen and phosphorus cycles. In: Tropical Mangrove Ecosystems. A. I. Robertson and D.M. Alongi (Eds.). 329 pp.American Geophysical Union. Washington D.C., U.S.A.

ArandaCicerol, N., J. A. Herrera-Silveira And F. A. Comín. 2006. Nutrient water quality in a tropical coastal zone with groundwater discharge, northwest Yucatán Mexico. Est. Coast Shelf Sci. 68: 445-454.

AsPILA, K .I., H. AgEMIAN AND S. Y. CHAU. 1976. A semi-automated method for determination of inorganic, organic and total phosphate in sediments. Analyst 101: 187-197.

Baldwin, A., M. Egnotovich, M. Ford And W. Platt. 2001. Regeneration in fringe mangrove forests damaged by hurricane Andrew. Plant Ecol. 157: 151-164.

BARBIER, E. B. 2006. Natural barriers to natural disasters: replanting mangroves after the tsunami. Front. Ecol. Environ. 4: 124-131.

Bauer-Gottwein, P., B. R. N. Gondwe, G. Charvet, L. E. Marin, M. RebolledoVieyra AND G. Merediz-Alonso. 2011. Review: The Yucatan Peninsula karst aquifer, Mexico. Hydrogeol. J. 19: 507-524. 
BedDows, P. A., P. L. SMART, F. F. WhitakeR AND S. L. SMith. 2007. Decoupled freshsaline groundwater circulation of a coastal carbonate aquifer: Spatial patterns of temperature and specific electrical conductivity. J Hydrol. 346: 18-32

Bouillon, S., A. V. Borges, E. Castañeda-Moya, K. Diele, T. Dittmar, N. C. Duke, E. KRistensen, S. Y. Lee, C. MARChand, J. J. Middelburg, V. H. RiveraMonRoy, T. J. SMITH AND R. R. TWILLEy. 2008. Mangrove production and carbon sinks: a revision of global budget estimates. Global Biogeochem. Cy. 22: 1-12.

BunT, J. S. 1995. Continental scale patterns in mangrove litter fall. Hydrobiol. 295: 135140.

CICESE, Centro de Investigación Científica y Educación Superior, Ensenada, Baja California México. Tide predictions for Mexico. Accessed November 2011. http://oceanografia.cicese.mx/predmar/calmen.php

CONABIO (Comisión Nacional de Biodiversidad), 2009. Manglares de México: Extensión y distribución, Comisión Nacional para el Conocimiento y Uso de la Biodiversidad, México DF, México.

CONABIO (Comisión Nacional de Biodiversidad), 2010. Portal de información geográfica. México, D.F. http://www.conabio.gob.mx/informacion/gis/. Accessed 10th April 2011.

ConNer, W. H., J. W. DAY, R. H. BAumann AND J. M. RANDALl. 1989. Influence of hurricanes on coastal ecosystems along the northern Gulf of Mexico. Wetl. Ecol. Manag. 1: 45-56.

CinTRÓN, G. AND SHAEFFER-NOVELLI, Y. 1984. Methods for studying mangrove structure. 91-13 p. In: Snedaker, S.C. y Snedaker, J.G. (eds.). The mangrove 
ecosystem: Research methods. Monographs on oceanographic methodology 8. UNESCO/SCOR. UK $251 \mathrm{p}$

Costanza, R., R. D'Arge, R. DE Groot, S. FARBer, M. Grasso, B. Hannon, K. Limburg, S. NAeEm, R. C. O'Neill, J. Paruelo, R. G. Gaskin, P. Sutton and M. VAN DEN BELT. 1997. The value of the world's ecosystem services and natural capital. Nature 387: 253-260.

Dahdoun-Guebas, F. AND N. KoEdam. Empirical estimate of the reliability of the use of Point Quarter Method (PCQM): Solutions to ambiguous field situations and Descriptions of the PCQM+ protocol. 2006. Forest Ecol. Manag. 228: 1-18 Day, J. W., C. Coronado-Molina, F. R. Vera-Herrera, R. Twilley, V. RiveraMonroy, H. Alvarez-Guillen, R. DAy, AND W. Conner.1996. A 7-year record of aboveground net primary production in a southeastern Mexican mangrove forest. Aquat. Bot. 55: 39-60.

DoYle, T. W., T. SMith AND M. B. RoBBLEE. 1995. Wind damage effects of hurricane Andrew on mangrove communities along the Southwest coast of Florida, U.S.A. J. Coast Res., 21: 159-168.

Enriquez, C., I. J. Meriño-Tapia And J. A. Herrera-Silveira. 2010. Dispersion in the Yucatan coastal zone: Implications for red tide events. Cont. Shelf. Res. 30: 127137FELLER, I. 1995. Effects of nutrient enrichment on growth and herbivory of dwarf mangrove (Rhizophora mangle). Ecol. Monogr. 65: 477-505.

GarCiA, E., P. Mosiño. 1992. Los climas de México, Vol. 2. Instituto de Geografía, UNAM, México, D.F. 
Gondwe, B.R. N, S-H. Hong, S. WdWOINSKi AND P. BAUER-GotTwein. 2010.

Hydrologic dynamics of the groundwater dependent Sian Ka'aan wetlands, Mexico, derived from InSAR and SAR data. 2010. Wetlands. 30: 1-13.

HernándeZ-Terrones, L., M. Rebolledo-Vieyra, M. Merino-IbArRA, M. Soto, A. Le-CosseC AND E. MonRoy-Ríos. 2011. Groundwater pollution in a karstic region (NE Yucatan): Baseline nutrient content and flux to coastal ecosystems. Water Air and Soil Pollution. 218: 517-528

HoldRige, L. R., W. C. GrenKe, W. H. Hathaway AND T. Liang. 1971. Forest enviroments in tropical life zones, a pilot study. Pergamon press, New York.

LEACH, G. J. AND S. BURGIN. 1985. Litter production and seasonality of mangroves in Papua New Guinea. Aquat. Bot. 23: 215-224.

LOVELOCK, C.E. AND I.C. FELLER. 2003. Photosynthetic performance and resource utilization of two mangrove species coexisting in a hypersaline scrub forest. Oecol. 134: 455-462

Lovelock, C. E., I. C. Feller, M. F. Adame, R. Reef, H. M. Penrose, L. Wei and M. BALL. 2011. Subsidies delivered by an intense storm relieve nutrient limitations in mangroves of an arid zone estuary. Funct. Plant Biol. 38: 514-522

LUGO, A. E., S. BROWN AND M. BRINSON. 1988. Forested wetlands in freshwater and saltwater environments. Limnol. Oceanogr. 33: 894-909.

Lugo, A. E. AND S. C. SNEDAKER.1974. The Ecology of Mangroves. Annu. Rev. Ecol. Syst. 5: 39-64. 
Middelburg, J. J., J. Nieuwenhuize, F.J. Slim And B. OHowa. 1996. Sediment

biogeochemistry in an East African mangrove forest (Gazi Bay, Kenya)

Biogochemistry 34: 133-155.

MumBY, P. J. 2006. Connectivity of reef fish between mangroves and coral reefs:

Algorithms for the design of marine reserves at seascape scales. Biol. Conserv.

128: $215-222$

NOAA (National Ocean and Atmospheric Administration). Historical hurricane tracks. U.S.A. http://csc.noaa.gov/hurricanes/. Accessed 23rd March 2011

O’BRIEN, R. M. (2007). A caution regarding rules of thumb for Variance Inflation Factors. Quality \& Quantity. 41: 673-690.

Odum, E. P., J. T. FinN AND E. H. Franz. 1979. Perturbation Theory and the subsidystress gradient. Bioscience. 29: 349-352

PARSONS, T. R., Y. MAitA, AND C. M. LALLI. 1984. A manual of chemical and biological methods for seawater analysis. Pergamon Press, NY, U.S.A.

POOL, D. J. AND S. C. SNEDAKER. 1975. Litter production in mangrove forests of southern Florida and Puerto Rico. In: Walsh GE, Snedaker SC, H.J. T (Eds) Proceedings of the international symposium on biology and management of mangroves, pp. 213237, University of Florida, Gainesville, U.S.A.

REJMÁNKOVÁ, E. 2001. Effects of experimental phosphorus enrichment on oligotrophic tropical marshes in Belize, Central America. Plant and Soil. 236: 33-53

Ross, M. S., P. L. Ruiz, J. P. SAH, D. L. Reed, J. WALters AND J. F. MeEder. 2006. Early post-hurricane stand development in fringe mangrove forests of contrasting productivity. Plant Ecol. 185: 283-297 
RoтH, L. C. 1992 Hurricanes and mangrove regeneration: effects of hurricane Joan, October 1988, on the vegetation of Isla del Venado, Bluefields, Nicaragua. Biotropica 24: 375-384

SAENGER, P. AND S. C. SNEDAKER. 1993. Pantropical trends in mangrove above-ground biomass and annual litterfall. Oecol. 96: 293-299

SChmitter-Soto, J. J., F. A. Comín, E. Escobar-Briones, J. HerRera-Silveira, J. AlCoCer , E. SuÁreZ-Morales, M. ElíAs-GutiérReZ, V. DíAZ-ArCe, L. E. MARÍN AND B. STEINICH. 2002. Hydrogeochemical and biological characteristics of cenotes in the Yucatan Peninsula (SE Mexico). Hydrobiologia 467: 215-228

SMN-CNA (Servicio Meteorologico Nacional-Comision Nacional del Agua) http://smn.cna.gob.mx/ . Accessed 10th April, 2011

Steinich, B AND L. E. MARíN. 1996. Hydrogeological investigations in Northwestern Yucatán, México, using resistivity surveys. Groundwater. 34: 640-646

TWILLEY, R. R., R. H. CHEN AND T. HARGIS. 1992. Carbon sinks in mangroves and their implications to carbon budget of tropical coastal ecosystems. Water Air Soil. Poll. 64: $265-288$

Twilley, R.R., M. Pozo, V. H. Garcia, V. H. Rivera-Monroy, R. ZMabrano, A. BODERO. 1997. Litter dynamics in riverine mangrove forests in the Guayas River estuary, Ecuador. 1997. Oecol. 111: 109-122.

Vazquez, P., G. Holguin, M.E. Puente, A. Lopez-Cortes and Y. Bahan. 2000. Phosphate solubilizing microorganisms associated with the rhizosphere of mangroves in a semiarid coastal lagoon. 2000. 30: 460-468. Biolog. Fertil Soils 
TABLE 1. Number of storms (S) and hurricanes (category 1 to 5; H1-H5) crossing through a $40 \mathrm{~km}$ radius of eight mangrove forests of the Yucatan Peninsula between 1857-2009 (NOAA, 2011). A Tropical Storm Index (TSI) was calculated from the frequency and mean wind velocity of each event.

\begin{tabular}{lccccccccc}
\hline & $\mathrm{S}$ & $\mathrm{H} 1$ & $\mathrm{H} 2$ & $\mathrm{H} 3$ & $\mathrm{H} 4$ & $\mathrm{H} 5$ & $\mathrm{~S} / 50 \mathrm{yr}$ & $\mathrm{H} / 50 \mathrm{yr}$ & $\mathrm{TSI}$ \\
\hline Celestun & 3 & 2 & 6 & 3 & 0 & 0 & 1.0 & 3.6 & 2.1 \\
Yucalpeten & 7 & 2 & 3 & 3 & 2 & 1 & 2.3 & 3.6 & 2.7 \\
Chelem & 7 & 2 & 3 & 3 & 2 & 1 & 2.3 & 3.6 & 2.7 \\
Dzilam & 2 & 3 & 1 & 3 & 2 & 3 & 0.7 & 4.0 & 2.7 \\
Rio Lagartos & 5 & 3 & 4 & 5 & 2 & 1 & 1.6 & 4.9 & 3.2 \\
Puerto Morelos & 14 & 1 & 9 & 1 & 1 & 2 & 4.6 & 4.3 & 3.7 \\
Xcalak & 7 & 3 & 2 & 1 & 0 & 1 & 2.3 & 2.3 & 1.9 \\
Chetumal & 7 & 1 & 1 & 1 & 0 & 2 & 2.3 & 1.6 & 1.7 \\
& & & & & & & & & \\
\hline
\end{tabular}


TABLE 2. Characteristics of eight mangrove forests distributed along the Yucatan Peninsula. Values are means and standard errors of sampling plots within each location. Superscripts letters represent significant differences among sites. Values in parentheses denote annual mean minimum and maximum salinity. No significant differences for $\mathrm{pH}, \mathrm{C}$ and $N$ were found.

\begin{tabular}{|c|c|c|c|c|c|c|c|}
\hline & Salinity & $\begin{array}{l}\text { Bulk } \\
\text { density } \\
\left(\mathrm{g} / \mathrm{cm}^{3}\right)\end{array}$ & $\mathrm{pH}$ & $\% \mathrm{C}$ & $\% \mathrm{~N}$ & $\% \mathrm{TP}$ & $\mathrm{N}: \mathrm{P}$ \\
\hline Celestun & $\begin{array}{c}44.6 \pm 9.6^{c} \\
\left(21.5^{b}-55.8^{b}\right) \\
61.0 \pm 13.9^{c}\end{array}$ & $0.39 \pm 0.03^{\mathrm{ab}}$ & $7.91 \pm 0.02$ & $21.97 \pm 0.04$ & $0.80 \pm 0.04$ & $0.109 \pm 0.013^{\mathrm{a}}$ & $16.6 \pm 2.7^{a b}$ \\
\hline Yucalpeten & $\begin{array}{l}\left(27.0^{\mathrm{b}}-73.7^{\mathrm{b}}\right) \\
47.9 \pm 11.1^{\mathrm{c}}\end{array}$ & $0.81 \pm 0.19^{\mathrm{bc}}$ & $7.09 \pm 0.27$ & $12.49 \pm 1.46$ & $0.55 \pm 0.13$ & $0.048 \pm 0.006^{\mathrm{ab}}$ & $26.5 \pm 9.2^{\mathrm{abc}}$ \\
\hline Chelem & $\begin{array}{c}\left(20.4^{b}-62.7^{b}\right) \\
47.3 \pm 7.8^{c}\end{array}$ & $0.29 \pm 0.01^{\mathrm{ab}}$ & $7.01 \pm 0.20$ & $18.14 \pm 0.96$ & $0.49 \pm 0.08$ & $0.099 \pm 0.016^{\mathrm{a}}$ & $11.0 \pm 0.9^{\mathrm{a}}$ \\
\hline Dzilam & $\begin{array}{l}\left(31.4^{\mathrm{b}}-55.4^{\mathrm{b}}\right) \\
45.5 \pm 12.5^{\mathrm{c}}\end{array}$ & $0.64 \pm 0.01^{\mathrm{bc}}$ & $7.88 \pm 0.02$ & $14.80 \pm 0.11$ & $0.23 \pm 0.04$ & $0.066 \pm 0.003^{\mathrm{ab}}$ & $7.9 \pm 1.8^{\mathrm{a}}$ \\
\hline Rio Lagartos & $\begin{array}{c}\left(25.2^{\mathrm{b}}-61.8^{\mathrm{b}}\right) \\
11.1 \pm 3.8^{\mathrm{b}}\end{array}$ & $0.08 \pm 0.02^{\mathrm{a}}$ & $7.55 \pm 0.05$ & $25.88 \pm 0.42$ & $1.82 \pm 0.39$ & $0.034 \pm 0.006^{c}$ & $118.1 \pm 5.7^{c}$ \\
\hline Pto.Morelos & $\begin{array}{l}\left(3.0^{\mathrm{a}}-17.0^{\mathrm{a}}\right) \\
47.3 \pm 0.8^{\mathrm{c}}\end{array}$ & $0.20 \pm 0.03^{\mathrm{ab}}$ & $7.00 \pm 0.12$ & $24.18 \pm 4.80$ & $1.21 \pm 0.33$ & $0.022 \pm 0.002^{\mathrm{c}}$ & $66.5 \pm 6.4^{\mathrm{ab}}$ \\
\hline Xcalak & $\begin{array}{c}\left(18.8^{\mathrm{b}}-60.7^{\mathrm{b}}\right) \\
3.1 \pm 2.4^{\mathrm{a}}\end{array}$ & $0.90 \pm 0.01^{\mathrm{c}}$ & $7.41 \pm 0.25$ & $13.95 \pm 0.13$ & $0.79 \pm 0.41$ & $0.019 \pm 0.001^{\mathrm{c}}$ & $41.7 \pm 20.2^{\mathrm{abc}}$ \\
\hline Chetumal & $\left(0^{\mathrm{a}}-6.6^{\mathrm{a}}\right)$ & $0.45 \pm 0.01^{\mathrm{ab}}$ & $7.39 \pm 0.06$ & $16.16 \pm 0.46$ & $1.21 \pm 0.05$ & $0.027 \pm 0.002^{c}$ & $123.2 \pm 0.2^{\mathrm{c}}$ \\
\hline
\end{tabular}


TABLE 3. Forest structure of eight mangrove forests distributed along the Yucatan

Peninsula. $C I=$ complexity index; $R m=$ Rhizophora mangle, $L r=$ Laguncunaria racemosa, $\mathrm{Ag}=$ Avicennia germinans, $\mathrm{Ce}=$ Conocarpus erectus. The mangrove forest $a t$ Chetumal was composed of a mixture of mangrove trees and terrestrial vegetation such as Pachira sp. Superscripts letters represent significant differences among sites. Diagonal hyphens were used when a species was not found in the forest.

\begin{tabular}{|c|c|c|c|c|c|c|c|c|c|}
\hline & Density & & Basal area & & & & & & \% Terrestrial \\
\hline & (trees/ha) & Height (m) & $\left(\mathrm{m}^{2} / \mathrm{ha}\right)$ & CI & $\% \mathrm{Rm}$ & $\% \mathrm{Lr}$ & $\% \mathrm{Ag}$ & $\% \mathrm{Ce}$ & sp \\
\hline Celestun & $2450 \pm 750$ & $5.3 \pm 0.0^{\mathrm{ab}}$ & $29.2 \pm 1.4^{\mathrm{a}}$ & $6.5 \pm 1.8^{\mathrm{ab}}$ & $26 \pm 26$ & $9 \pm 9$ & $66 \pm 35$ & - & - \\
\hline Yucalpeten & $4500 \pm 400$ & $2.0 \pm 0.3^{\mathrm{d}}$ & $5.8 \pm 0.5^{\mathrm{b}}$ & $1.1 \pm 0.7^{\mathrm{b}}$ & $14 \pm 14$ & $20 \pm 20$ & $67 \pm 34$ & - & - \\
\hline Chelem & $3250 \pm 1350$ & $4.2 \pm 0.1^{\mathrm{bc}}$ & $32.2 \pm 12^{\mathrm{a}}$ & $10.8 \pm 6.0^{\mathrm{ab}}$ & $25 \pm 10$ & $70 \pm 5$ & $6 \pm 6$ & - & - \\
\hline Dzilam & $1683 \pm 200$ & $4.2 \pm 0.1^{\mathrm{bc}}$ & $6.2 \pm 0.3^{\mathrm{abc}}$ & $1.3 \pm 0.1^{\mathrm{ab}}$ & $38 \pm 2$ & $50 \pm 9$ & $13 \pm 7$ & - & - \\
\hline Rio Lagartos & $2200 \pm 200$ & $3.3 \pm 0.0^{c}$ & $2.1 \pm 0.0^{c}$ & $0.5 \pm 0.1^{\mathrm{b}}$ & $38 \pm 18$ & $59 \pm 14$ & $3 \pm 4$ & - & - \\
\hline Pto. Morelos & $5900 \pm 1453$ & $4.3 \pm 0.4^{\mathrm{bc}}$ & $19.6 \pm 7.1^{\mathrm{a}}$ & $17.6 \pm 9.3^{\mathrm{a}}$ & $13 \pm 12$ & $38 \pm 28$ & - & $48 \pm 26$ & - \\
\hline Xcalak & $6700 \pm 1000$ & $4.5 \pm 0.2^{\mathrm{bc}}$ & $14.6 \pm 1.9^{\mathrm{a}}$ & $4.5 \pm 1.4^{\mathrm{ab}}$ & $100 \pm 0$ & - & - & - & - \\
\hline Chetumal & $1750 \pm 350$ & $5.7 \pm 0.0^{\mathrm{a}}$ & $23.2 \pm 3.7^{\mathrm{a}}$ & $7.2 \pm 2.5^{\mathrm{ab}}$ & $21 \pm 4$ & - & - & $18 \pm 11$ & $62 \pm 7$ \\
\hline
\end{tabular}


TABLE 4. Litterfall rates $\left(\mathrm{g} / \mathrm{m}^{2}\right.$ d) of eight mangrove forests in the Yucatan Peninsula, Mexico. Litter was collected for two years (2009-2010). Superscripts indicate significant difference among sites; bold fonts indicate significant difference between years.

\begin{tabular}{llll}
\hline \multicolumn{2}{l}{ Litterfall $\left(\mathrm{g} / \mathrm{m}^{2} \mathrm{~d}\right)$} & & \\
& Mean & 2009 & 2010 \\
\hline Celestun & $2.90^{\mathrm{a}} \pm 0.34$ & $2.89 \pm 0.31$ & $2.91 \pm 0.64$ \\
Yucalpeten & $2.94^{\mathrm{a}} \pm 0.25$ & $2.73 \pm 0.22$ & $3.14 \pm 0.45$ \\
Chelem & $3.23^{\mathrm{a}} \pm 0.38$ & $3.08 \pm 0.34$ & $3.37 \pm 0.68$ \\
Dzilam & $3.48^{\mathrm{a}} \pm 0.40$ & $3.19 \pm 0.35$ & $3.75 \pm 0.68$ \\
R.Lagartos & $1.94^{\mathrm{b}} \pm 0.32$ & $\mathbf{1 . 8 7} \pm \mathbf{0 . 2 2}$ & $\mathbf{2 . 0 3} \pm \mathbf{0 . 6 8}$ \\
Pto.Morelos & $1.69^{\mathrm{b}} \pm 0.15$ & $1.74 \pm 0.16$ & $1.85 \pm 0.24$ \\
Xcalak & $1.98^{\mathrm{b}} \pm 0.21$ & $1.67 \pm 0.17$ & $2.33 \pm 0.38$ \\
Chetumal & $1.96^{\mathrm{b}} \pm 0.23$ & $1.88 \pm 0.37$ & $1.70 \pm 0.37$ \\
\hline Total & $2.41 \pm 0.26$ & $\mathbf{2 . 3 8} \pm \mathbf{0 . 2 3}$ & $\mathbf{2 . 6 3} \pm \mathbf{0 . 2 7}$ \\
\hline
\end{tabular}


FIGURE 1. Sampling sites within eight mangrove forests of the Yucatan Peninsula, Mexico. Shaded regions represent areas of mangrove forest (map of mangrove area obtained from CONABIO, 2010).

FIGURE 2. Correlation between the two principal components (PC1 and PC2) derived from two Principal Component Analysis: (A) soil characteristics (nitrogen (N), total phosphorus (TP), carbon (C), bulk density and $\mathrm{pH}$ ) and interstitial salinity, and (B) forest structure (height, tree density and basal area (BA)). Sites in panel A are grouped in three clusters representing geographical location: northwest, northeast and southeast of the Yucatan Peninsula.

FIGURE 3. Litterfall rates $\left(\mathrm{g} / \mathrm{m}^{2} \mathrm{~d}\right)$ for eight mangrove forests distributed around the Yucatan Peninsula coast from 2009 to 2010.

FIGURE 4. Relation between litterfall rates $\left(\mathrm{g} / \mathrm{m}^{2} \mathrm{~d}\right)$ and hurricane intensity and frequency calculated as a Tropical Storm Index (see Methods) for eight mangrove forests distributed within the coast of the Yucatan Peninsula (northwest, northeast and southeast). The correlation is significant $\left(R^{2}=0.79, F_{2,5}=9.15, P=0.009\right)$ and the curve is represented by the formula $y=-1.46 x^{2}+7.60 x-6.83$.

FIGURE 5. Relation between mean litterfall rates $\left(\mathrm{g} / \mathrm{m}^{2} \mathrm{~d}\right)$ per site and soil total phosphorus (log TP (\%) +2). 


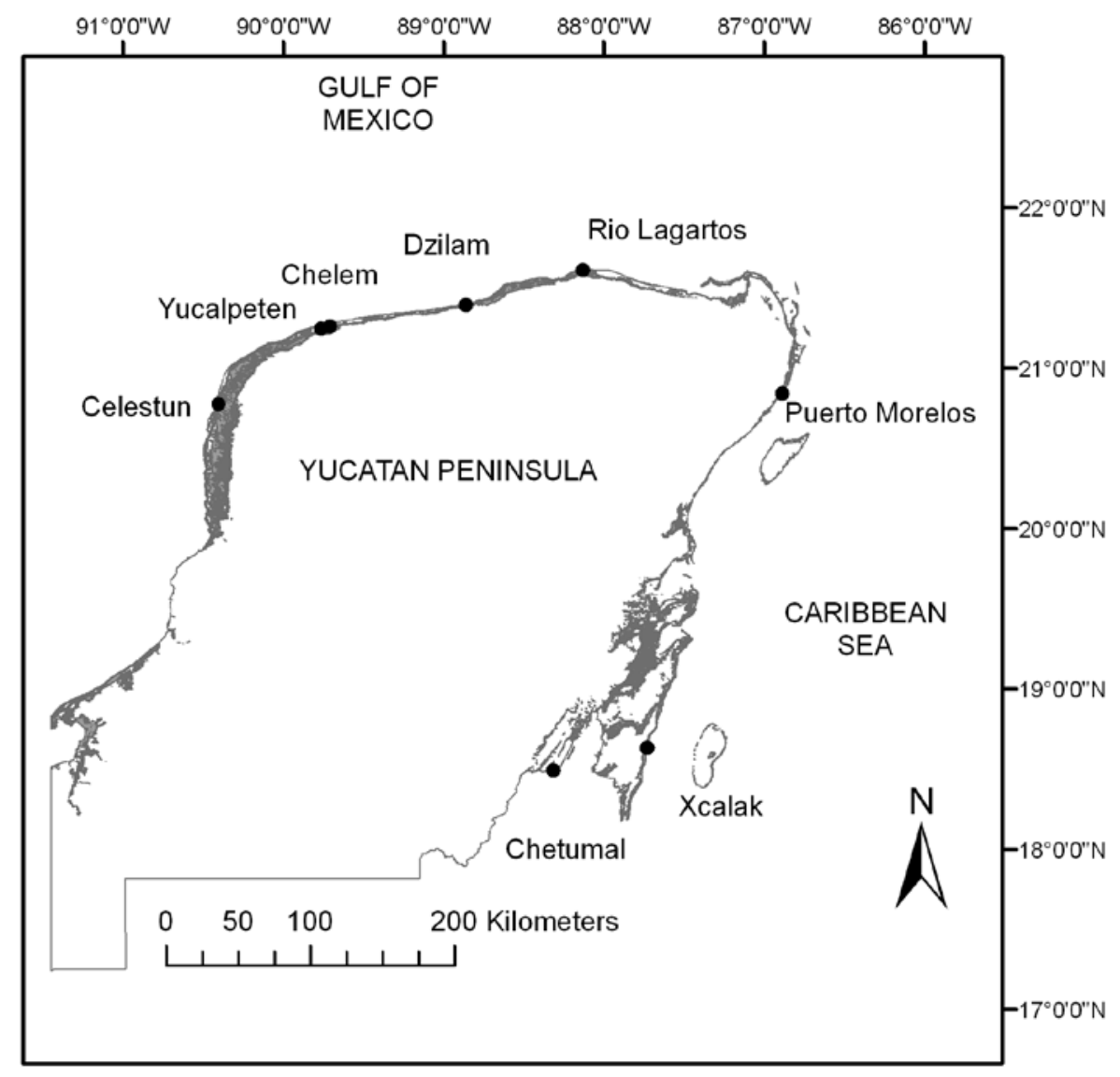

FIGURE 1. 


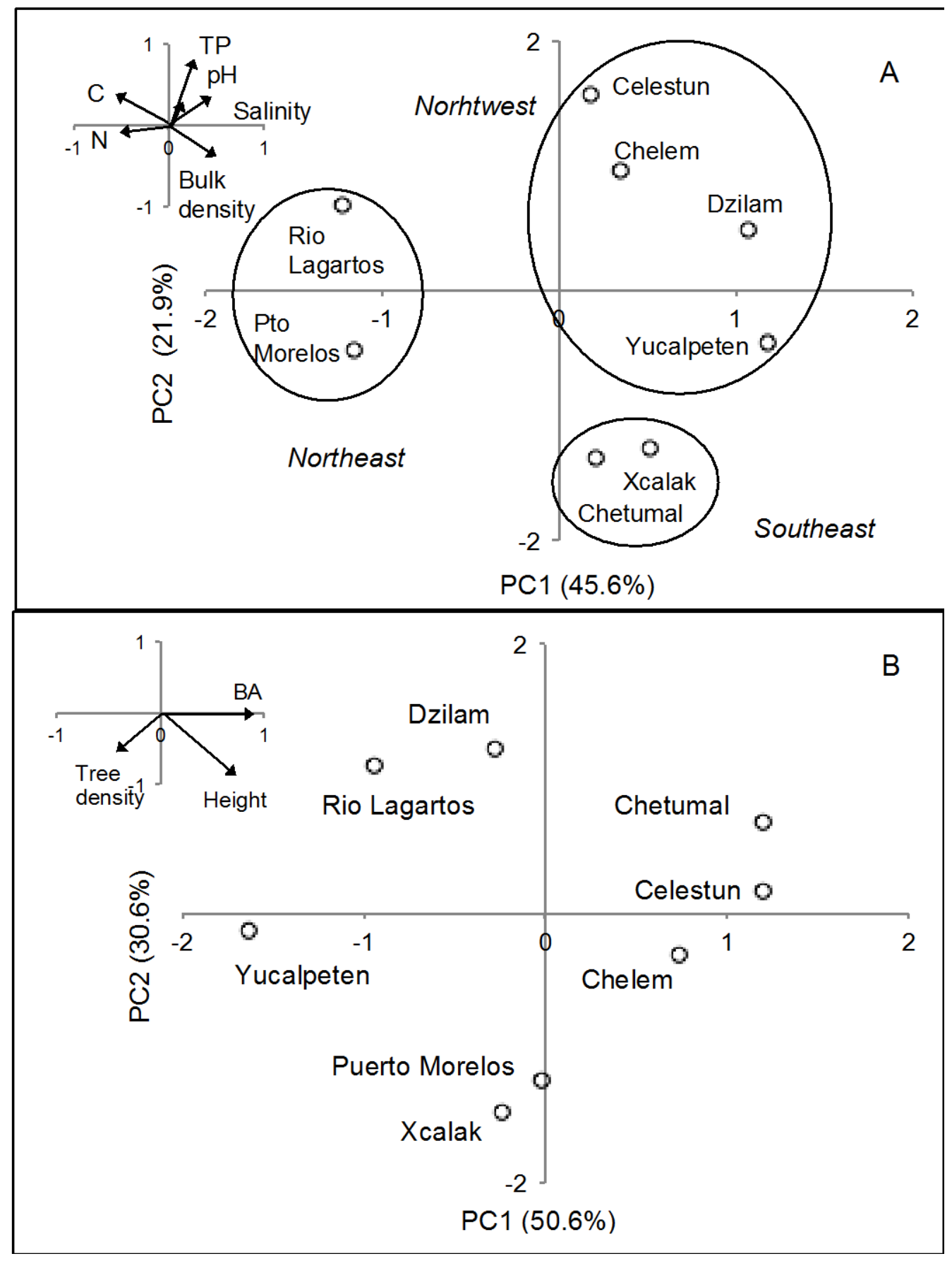




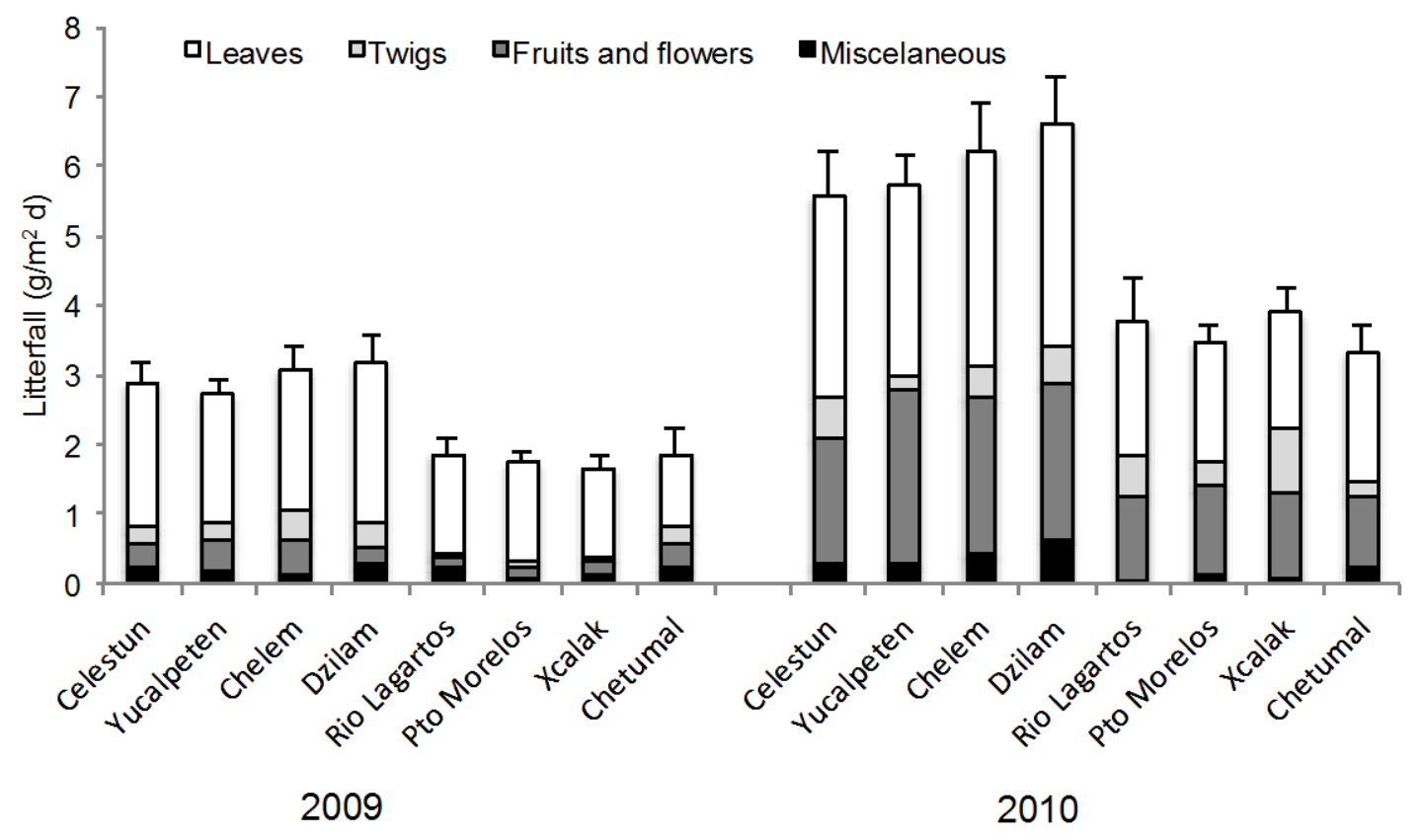

FIGURE 3. 


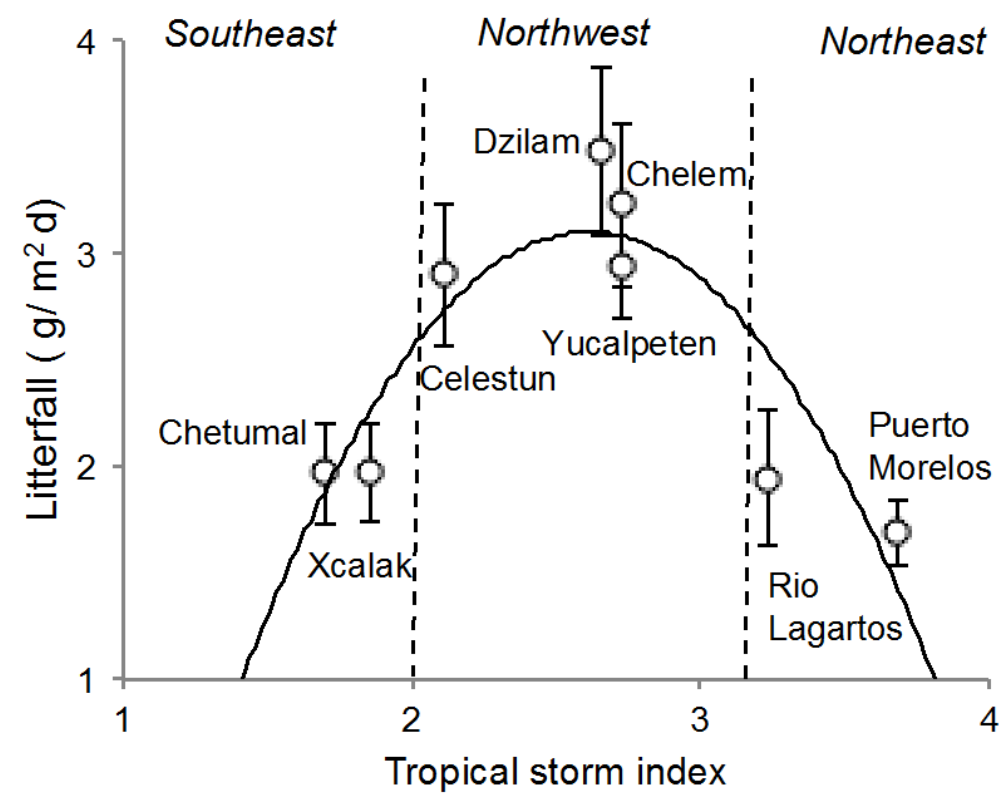

FIGURE 4. 


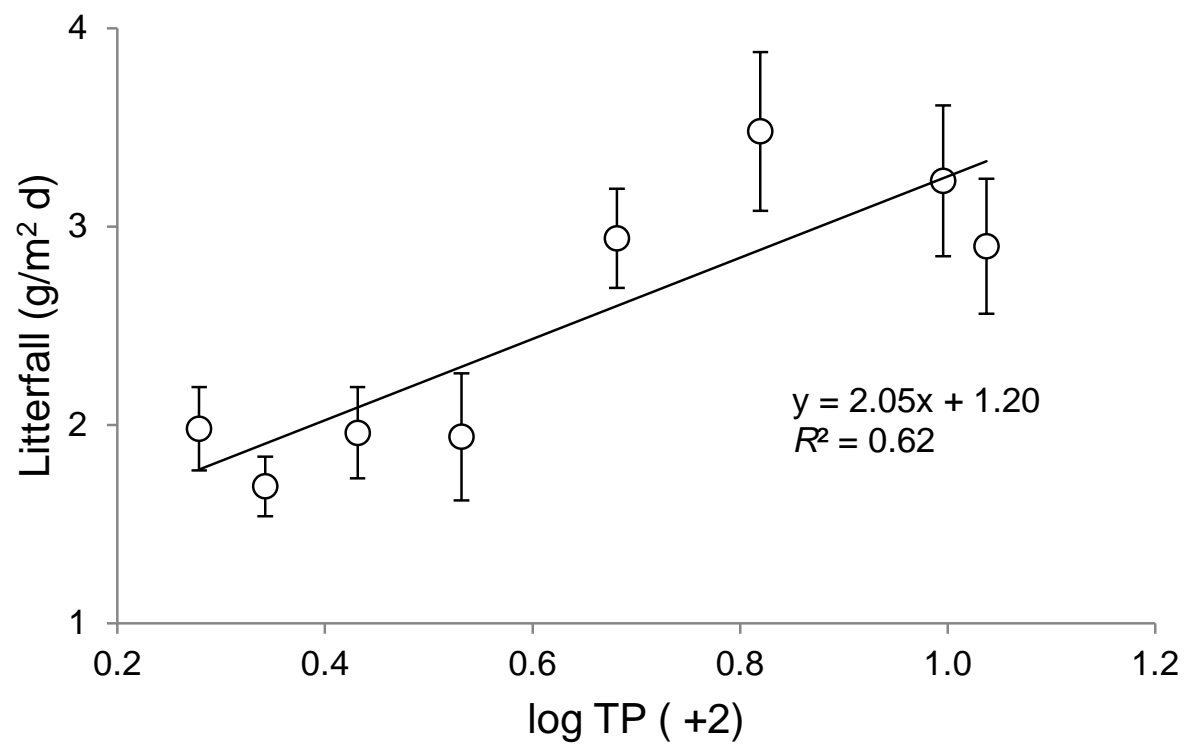

FIGURE 5 